\title{
Acceptance of Technology by Islamic Boarding School Students Based on the TAM Model
}

\author{
Nuryanna1 ${ }^{1}$ Nurulwati ${ }^{1}$, A Halim ${ }^{1,2 *}$, Elmi Mahzum¹ ${ }^{1}$ Abdul Hamid 1 \\ ${ }^{1}$ Science Education Study Program, Postgraduate Program, Syiah Kuala University, Banda Aceh, Indonesia \\ ${ }^{2}$ Department of Physical Education, Faculty of Teacher Training and Education, Syiah Kuala University, Banda Aceh, Indonesia
}

DOI: $\underline{10.29303 / \text { ippipa.v7iSpecialIssue.825 }}$

\section{Article Info}

Received : June 30th, 2021

Revised : November $25^{\text {th }}, 2021$

Accepted: December 6th 2021

\begin{abstract}
This study aims to determine the acceptance of technology in Islamic boarding schools and their use in terms of physics learning outcomes, it is necessary to conduct research on technology acceptance among Islamic boarding schools. In this study, the acceptance of the technology was measured using the TAM model. Measurements were carried out in several Islamic boarding schools in the Aceh Besar area. The instrument used is a questionnaire on the perception of acceptance of information technology and documentation in the form of students' scores. The results obtained are the perception of students' acceptance of technology consisting of five indicators, namely the perception of PEOU (Perceived Ease of Use), PU (Perceived Usefulness), ATU (Attitude Toward Using), AU (Actual Usage), and B (Behavioral) towards information technology. Towards students tend to be high, and if there is the influence of other variables and not included in the study, so it can be seen that technology acceptance tends to be high. There is a strong relationship between Perceived Ease of Use (PEOU) and Perceived Usefulness (PU), PEOU and Attitude Toward Using (ATU), and Behavioral Intention (B) and Actual Usage (AU).
\end{abstract}

Keywords: Admissions; Information Technology; Islamic Boarding Schools; Physics Learning Outcomes

Citation: Nuryanna, N., Halim, A., Mahzum, E.., \& Hamid, A. (2021). Acceptance of Technology by Islamic Boarding School Students Based on the TAM Model. Jurnal Penelitian Pendidikan IPA, 7(Speciallssue), 194-198. https://doi.org/10.29303/jppipa.v7iSpeciallssue.825

\section{Introduction}

Technology-based learning cannot be separated from the guidance of 21st-century learning. According to Yusuf, et al (2015), technology which was originally only a tool, has developed a further role, namely providing opportunities to be able to simulate materials that are difficult to present, especially related to abstract physical phenomena. One of them is information technology which now plays a role in simulating materials that are difficult to present, especially related to abstract physical phenomena. Physics as one of the sciences whose concepts are mostly abstract and play a role in supporting the development of science and technology. The availability of technology as an educational medium can make it easier for individuals to study learning materials, resulting in better learning. According to Hariadi, (2016), the use of information and communication technology can improve student learning outcomes.

In this day and age, there are many schools and institutions, both formal and private, such as Islamic boarding schools. As an educational institution, Islamic boarding schools are not only equipped with religious knowledge but also other integrated sciences such as physics, chemistry, and biology and are required to speak foreign languages such as Arabic and English.

Based on the results of an interview with a physics teacher at a modern Islamic boarding school in

\footnotetext{
*Email: abdul.halim@unsyiah.ac.id
} 
Siem, Aceh Besar. Researchers obtained information that the pesantren has used information technology devices such as computers, focus, TV, and Internet facilities. There are several opinions from students in grades $\mathrm{X}$ and XII at the pesantren that students prefer to study with focus rather than when learning manually using the blackboard. However, they still feel various obstacles, such as the absence of supporting facilities such as the internet because it is only for teachers and computers which are also not owned by all students except in Vocational High Schools.

Therefore, there are differences in views between several previous studies by Arif, (2016) and Iryana, (2015) regarding the gaps and lagging behind in technology for students who study in Islamic boarding schools as one of the educational institutions, with the facts found in the field related that there are Islamic boarding schools that have provided information technology tools as learning facilities, such as science lessons and tend to be of interest to students and accepted by pesantren. Not only that, several previous research results also reveal that the availability of information technology as an educational medium can make it easier to study learning materials, thus providing better learning outcomes.

Based on the background of the problems stated above, the purpose of this study is to determine the acceptance of information technology, the type of information technology used among Islamic boarding schools in terms of physics learning outcomes. So that it can provide knowledge about the acceptance of information technology, the types of information technology used among Islamic boarding schools and the relationship with physics learning outcomes.

\section{Method}

\section{Approach and Model}

The approach used includes descriptive quantitative research, with the product-moment correlation approach developed by Pearson. This data analysis is used to determine the relationship between variables. The TAM model was chosen because it is a technology acceptance model used to explain the individual acceptance of the use of information technology systems (Jogiyanto, 2008). other than that, Fatmawati, (2015) stated that to analyze the acceptance of information technology (IT) with the TAM model. Based on Wibowo, (2016) research article, it is known that the emergence of feelings of acceptance or rejection refers to attitudes towards the use of information systems so that it affects user behavior towards the use of information systems. This study examines the behavior of information system users in a higher education institution with the Technology Acceptance Model (TAM) approach. The result is that there is an influence between Perceived Ease of Use (PEOU) on Perceived Usefulness (PU), Perceived Usefulness (PU) on Attitude Toward Using (ATU), Attitude Toward Using (ATU) on Behavioral Intention to Use (ITU), Perceived Usefulness ( PU) on Behavioral Intention to Use (ITU), Behavioral Intention to Use (ITU) on Actual System Usage (ASU), but there is no effect between perceptions of ease of use of the web (PEOU) and attitudes of use (ATU). In line with the results of research conducted by Safitri, (2015) that PU, PEOU, ITU, ASU have a significant effect on virtual class and the average respondent agrees that the virtual class website is of good value.

\section{Population and Sample}

Considering the limited time, limited funds, very large area according to the number of samples specified. The population of the pesantren used was only 4 randomly selected pesantren in the district of Aceh Besar, namely Dayah Darul Ihsan Tgk. H. Hasan Krueng Kalee in Siem, Lambaro Angan, Tgk Modern Islamic Boarding School. Chik Eumpe Awee in the Montasik sub-district, the Modern Al-Falah Abu Lam U Islamic boarding school in the Want Jaya sub-district and Dayah Darul Muta'allimin in the Blang Bintang sub-district.

Sampling using purposive sampling technique. In this study, the researcher used the Slovin formula to determine the sample size. The students who were asked to be respondents were from class XII at the high school level considering that they had been living in Islamic boarding schools for a long time. With a sample of each student per class XII, each boarding school is 25 students, because there are four Islamic boarding schools chosen by researchers, a total sample of 100 samples will be collected.

\section{Data collection}

Data collection is done by providing questionnaires and documentation of the value of learning outcomes. According to Sugiyono (2013), questionnaire is a data collection technique by giving a set of questions or written statements to respondents to answer. Questionnaires were distributed to students to find out how they perceive the use of information technology. Meanwhile, the documentation of the students' physics scores was obtained from the teacher in the field of physics subject.

Research using the TAM (Technology Acceptance Model) model has5 main constructs, namely: (1) Perceived usefulness, (2) Perceived ease of use, (3) Attitude toward using (attitude), (4) Behavioral 
intention to use (intentions), and (5) Actual technology use.

\section{Result and Discussion}

The results of the analysis of the relationship acceptance of information technology among Islamic boarding school students based on the interrelationships between indicators in the TAM model can be seen based on Figure 1.

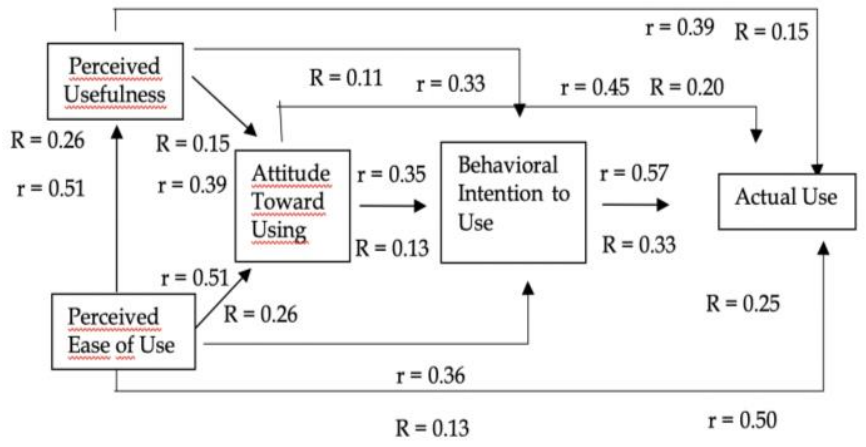

Figure 1. The relationship between indicators in the TAM

(Technology Acceptance Model) research model

Based on Figure 1, it is known that the correlation coefficient (r) between all variables is positive, meaning that the higher the value of a variable, the greater the value of the other variable. Only on the indicators PEOU with PU (convenience and benefits), PEOU with ATU (ease and attitude), and $\mathrm{B}$ with AU (behavior and use) only the correlation coefficient (r) is worth which is rounded up to one (0.51, 0.51 and 0.57) means that there is a strong positive correlation (the higher the value of the indicator, the higher the value of the other indicator, and vice versa). While the coefficient of determination
(R) of (0.26 0.26 and 0.33$)$ means that the perception of ease and benefits of use contributes $26 \%$ to the acceptance of information technology, the perception of convenience and attitude contributes $26 \%$ to the acceptance of information technology, then behavior and actual use contributed $33 \%$ to the acceptance of information technology. This means that there is a strong relationship between perceived Ease of Use (PEOU) with Perceived Usefulness (PU) (ease and benefit), PEOU with Attitude Toward Using (ATU) (ease and attitude), and Behavioral Intention (B) with Actual System Usage (ASU) (behavior and use).

In line with the research results of Wibowo (2006) that there is an influence between Perceived Ease of Use (PEOU) on Perceived Usefulness (PU), Perceived Usefulness (PU) on Attitude Toward Using (ATU), Attitude Toward Using (ATU) on Behavioral Intention to Use (ITU), Perceived Usefulness (PU) on Behavioral Intention to Use (ITU), Behavioral Intention to Use (ITU) on Actual System Usage (ASU), but there is no influence between perceptions of ease of use of the web (PEOU) and usage attitudes (ATU). Likewise with the results of research conducted by Safitri, (2015) that "PU, PEOU, ITU, ASU have a significant effect on the virtual class and the average respondent agrees that the virtual class website is of good value".

\section{Acceptance of Information Technology Using the TAM Model in Terms of Learning Outcomes by Gender}

Student learning outcomes can be categorized into three categories, namely high, medium and low. Researchers divide the categorization of technology acceptance among students in terms of physics learning outcomes based on gender, as follows:

Table 1. Correlation value of information technology acceptance indicators using the TAM model on learning outcomes with male gender

\begin{tabular}{|c|c|c|c|c|c|c|c|c|c|}
\hline \multirow[t]{2}{*}{ No } & \multirow{2}{*}{ Indicator } & \multicolumn{2}{|l|}{ Tall } & \multicolumn{2}{|c|}{ Currently } & \multicolumn{2}{|l|}{ Low } & \multicolumn{2}{|c|}{ Average } \\
\hline & & r & $\mathrm{R}$ & $\mathrm{r}$ & $\mathrm{R}$ & $\mathrm{r}$ & $\mathrm{R}$ & $\mathrm{r}$ & $\mathrm{R}$ \\
\hline 2 & PEOU - ATU & 0.42 & 0.17 & 0.58 & 0.33 & 0.53 & 0.28 & 0.52 & 0.27 \\
\hline 4 & PEOU - AU & 0.09 & 0.01 & 0.56 & 0.31 & 0.50 & 0.25 & 0.48 & 0.24 \\
\hline 5 & PU - B & -0.75 & 0.56 & 0.42 & 0.18 & 0.33 & 0.11 & 0.23 & 0.05 \\
\hline 6 & $\mathrm{PU}-\mathrm{AU}$ & 0.38 & 0.14 & 0.68 & 0.47 & 0.09 & 0.01 & 0.49 & 0.24 \\
\hline 9 & ATU - AU & 0.44 & 0.19 & 0.45 & 0.20 & 0.52 & 0.27 & 0.43 & 0.19 \\
\hline 10 & SMELL & 0.06 & 0.00 & 0.57 & 0.32 & 0.95 & 0.91 & 0.59 & 0.35 \\
\hline
\end{tabular}

Based on the data in the table above, it is known that in the male gender with high, medium, low learning outcomes and the average learning outcomes of the students, the correlation coefficient (r) between all variables is positive, meaning that the higher the value of an indicator, the indicator value the other will 
be great too. However, in high learning outcomes, PU with B, ATU with B has a negative correlation coefficient $(r)$, meaning that the lower the value of an indicator, the value of the other indicator will also be small.

In high learning outcomes data, only the PU with $\mathrm{B}$ and PU with ATU indicators have the correlation coefficient $(\mathrm{r})$ which is worth rounding up to one $(0.75$ and 0.54$)$. While the coefficient of determination (R) is (0.56 and 0.29) means that actual use and behavior contribute $56 \%$ to information technology acceptance, actual use and attitude contribute $29 \%$ to information technology acceptance.

On the data of moderate learning outcomes, only on the indicators PEOU with PU, PEOU with ATU, PEOU with AU, PU with AU, and B with AU only the correlation coefficient $(\mathrm{r})$ is worth which is rounded up to one $(0.60,0.58,0.56,0.68$ and 0.57$)$ means that they are highly positively correlated. While the coefficient of determination $(R)$ of $(0.36,0.33,0.31,0.47$, and 0.32$)$ means that the perception of ease and benefits of use contributes $36 \%$ to the acceptance of information technology, the perception of convenience and attitude contributes by $33 \%$ of the acceptance of information technology, the perception of ease and use contributed by $31 \%$ to the acceptance of information technology, the perception of benefits and convenience contributed $47 \%$ to the acceptance of information technology,

In low learning outcomes data, only the PU with $\mathrm{B}$ indicators, and PU with AU only have a low correlation coefficient ( $\mathrm{r}$ ), which if rounded up to close to zero (0.33 and 0.09$)$ means that there is a low positive correlation. While the coefficient of determination (R) of (0.11 and 0.01) means that benefits and behavior contribute $11 \%$ to the acceptance of information technology, the benefits and use actually contribute $1 \%$ to the acceptance of information technology.

Based on the overall learning outcomes, only on the PEOU indicator with ATU and B with AU only the correlation coefficient $(\mathrm{r})$ is worth which when rounded to close to one (0.52 and 0.59), means that the correlation is moderately positive. While the coefficient of determination $(R)$ is $(0.27$ and 0.35$)$, meaning that the perception of convenience and attitude contributes $27 \%$ to the acceptance of information technology, then behavior and actual use contribute $35 \%$ to the acceptance of information technology.

Table 2. Correlation value of information technology acceptance indicators using the TAM model on learning outcomes with female gender

\begin{tabular}{llllllllll}
\hline \multirow{2}{*}{ No } & \multirow{2}{*}{ Indicator } & \multicolumn{3}{c}{ Tall } & \multicolumn{2}{c}{ Currently } & Low & \multicolumn{2}{c}{ Average } \\
\cline { 2 - 8 } & & $\mathrm{r}$ & $\mathrm{R}$ & $\mathrm{r}$ & $\mathrm{R}$ & $\mathrm{r}$ & $\mathrm{R}$ & $\mathrm{r}$ \\
\hline 1 & PEOU- PU & 0.46 & 0.21 & 0.78 & 0.61 & -0.16 & 0.02 & 0.56 \\
2 & PEOU - ATU & 0.46 & 0.21 & 0.59 & 0.35 & -0.16 & 0.02 & 0.49 & 0.31 \\
3 & PEOU - B & 0.44 & 0.19 & 0.18 & 0.03 & -0.06 & 0.00 & 0.28 & 0.24 \\
4 & PEOU - AU & 0.35 & 0.12 & 0.53 & 0.29 & -0.04 & 0.00 & 0.42 & 0.18 \\
5 & PU - B & 0.53 & 0.28 & 0.34 & 0.12 & 0.38 & 0.14 & 0.43 & 0.19 \\
6 & PU - AU & 0.34 & 0.12 & 0.55 & 0.30 & 0.13 & 0.02 & 0.41 & 0.17 \\
7 & PU - ATU & 0.24 & 0.06 & 0.44 & 0.20 & 0.00 & 0.00 & 0.32 & 0.11 \\
8 & ATU - B & 0.42 & 0.17 & 0.51 & 0.26 & 0.36 & 0.13 & 0.43 & 0.19 \\
9 & ATU - AU & 0.35 & 0.12 & 0.46 & 0.21 & -0.17 & 0.03 & 0.33 & 0.11 \\
10 & SMELL & 0.67 & 0.45 & 0.46 & 0.21 & 0.33 & 0.11 & 0.55 & 0.31 \\
\hline
\end{tabular}

Based on the data in the table above, it is known that in the female gender with high, medium, low learning outcomes and the average student learning outcomes have a correlation coefficient (r) between all variables is positive, meaning that the higher the value of an indicator, the value of the other indicator will go big. However, in low learning outcomes, PEOU with PU, PEOU with B, PEOU with ATU, PEOU with AU, and ATU with AU have a negative correlation coefficient (r), meaning that the lower the value of an indicator, the value of the other indicator will also be small.

In high learning outcomes data, only the PU with $\mathrm{B}$ and $\mathrm{B}$ and $\mathrm{AU}$ indicators have the correlation coefficient $(r)$ which is worth rounding up to one $(0.53$ and 0.67 ) while the coefficient of determination (R) is
(0.28 and 0.45$)$ meaning that benefits and behavior contribute $28 \%$ to the acceptance of information technology, behavior and use actually contribute $45 \%$ to the acceptance of information technology.

On the data of moderate learning outcomes, only on the indicators PEOU with PU, PEOU with ATU, PEOU with AU, PU with AU, and ATU with B only the correlation coefficient $(\mathrm{r})$ is worth which if rounded up to one $(0.78,0.59,0.53,0.55$ and 0.51$)$ means that they are correlated positive high. While the coefficient of determination $(\mathrm{R})$ of $(0.61,0.35,0.29,0.30$, and 0.26$)$ means that the perception of ease and benefit of use contributes $61 \%$ to the acceptance of information technology, the perception of convenience and attitude contributes by $35 \%$ of acceptance of information technology, perceived ease and use contributed $29 \%$ to 
acceptance of information technology, perceived benefits and usage contributed 30\% to acceptance of information technology, then attitudes and behavior contributed $26 \%$ to acceptance of information technology.

In low learning outcomes data, all indicators have a low correlation coefficient ( $r$ ) which, when rounded off, is close to zero. And the coefficient of determination (R) is low and even tends not to exist $(0 \%)$ towards the acceptance of information technology

Based on the overall learning outcomes, only on the PEOU indicator with PU and B with AU only the correlation coefficient $(r)$ is worth which, if rounded up to close to one (0.56 and 0.55), means that it is correlated being positive. While the coefficient of determination (R) is both (0.31) meaning that the perception of convenience and benefits contributes $31 \%$ to the acceptance of information technology, then behavior and actual use contribute $31 \%$ to the acceptance of information technology.

\section{Conclusion}

The results obtained are the perception of students' acceptance of technology consisting of 5 indicators, namely the perception of PEOU (Perceived Ease of Use), PU (Perceived Usefulness), ATU (Attitude Toward Using), AU (Actual Usage) and B (Behavioral) towards information technology towards students tends to be high, and if there is the influence of other variables and is not included in the study. So, it can be seen that the acceptance of technology tends to be high. And there is a strong relationship between Perceived Ease of Use (PEOU) and Perceived Usefulness (PU), PEOU and Attitude Toward Using (ATU), and Behavioral Intention (B) and Actual Usage (AU). With the contribution of perceived ease of use and usefulness of use equal to the contribution of perceived ease of use and attitude.

\section{Acknowledgment}

The author would like to thank those who have guided the research of Dr. A. Halim, M.Si and Drs. Elmi Mahzum, M.IT, and Drs. Agus Wahyuni, M.Pd as the validator of the research instrument. Thanks, were also conveyed to the class XII SMAS/MAS Islamic boarding schools in Dayah Darul Ihsan Tgk. H. Hasan Krueng Kalee in Lambaro Angan, Modern Eumpe Awee Islamic Boarding School in Montasik District, Modern Al-Falah Abu Lam U Islamic Boarding School in Want Jaya District and Dayah Darul Muta'allim in Blang Bintang District, Aceh Besar.

\section{References}

Arif, M. (2016). Perkembangan Pesantren Di Era Teknologi. Jurnal Pendidikan Islam, 28(2), 307-322. doi:https://doi.org/10.15575/jpi.v28i2.550 [Indonesian]

Fatmawati, E. (2015). Technology Acceptance Model (TAM) untuk Menganalisis Sistem Informasi Perpustakaan. Iqra': Jurnal Perpustakaan Dan Informasi, 9(1), 1-13. http://jurnal.uinsu.ac.id/index.php/iqra/article $\angle$ view /66 [Indonesian]

Hariadi., Nuraini., \& Achmadi. (2016). Pemanfaatan Teknologi Informasi Dan Komunikasi Terhadap Hasil Belajar Pada Mata Pelajaran Ekonomi Di SMA. Jurnal Pendidikan dan Pembelajaran. 5(10). 1$12 . \quad$ Retrieved from: https://jurnal.untan.ac.id/index.php/jpdpb/art icle/view $/ 17130 / 0$ [Indonesian]

Iriana, W. (2015). The Challenge of Salaf Islamic Boarding Schools in the Modern Era. $A L-$ MURABBI Journal, 2(1). Retrieved from: http://ejournal.kopertais4.or.id/mataraman/in dex.php/murabbi/article/view/426

Jogiyanto. (2008). Behavioral Information System. Yogyakarta: Andi.

Safitri, L. (2015). Pengukuran Penerimaan Teknologi Virtual Class Pada Mahasiswa Dengan Menggunakan Metode Tam Dan Webqual. UG Jurnal. 7(11). Retrieved from: https://ejournal.gunadarma.ac.id/index.php/u gjournal/article/view/1495 [Indonesian]

Setiawan, A. (2012). Penanggulangan Dampak Negatif Akses Internet di Pondok Pesantren melalui Program Internet Sehat. Jurnal Penelitian Komunikasi, 15(1). doi:https:// doi.org/10.20422/jpk.v15i1.706 [Indonesian]

Sugiyono. (2013). Metode Penelitian Pendidikan Pendekatan Kuantitatif, Kualitatif, dan RED. Bandung: Alfabeta [Indonesian]

Wibowo, A. (2008). Kajian Tentang Perilaku Pengguna Sistem Informasi Dengan Pendekatan Technology Acceptance Model (TAM). Jakarta Selatan: Program Studi Sistem Informasi, Fakultas Teknologi Informasi Universitas Budi Luhur. [Indonesian]

Yusuf, I., Widyaningsih, S., \& Purwati, D. (2015). Pengembangan Perangkat Pembelajaran Fisika Modern Berbasis Media Laboratorium Virtual Berdasarkan Paradigma Pembelajaran Abad 21 Dan Kurikulum 2013. Pancaran Pendidikan, 4(2), 189-200. from 
https://jurnal.unej.ac.id/index.php/pancaran/a rticle/view/1563 [Indonesian] 